\title{
FAULTING CAUSED BY EARTHQUAKES BENEATH THE OUTER SLOPE OF THE JAPAN TRENCH
}

\author{
Tetsuzo SeNo* and Douglas Garcia Gonzalez**,1 \\ * International Institute of Seismology and Earthquake Engineering, \\ Building Research Institute, Tsukuba, Japan \\ ** Earthquake Research Institute, The University of Tokyo, \\ Tokyo, Japan
}

(Received September 18, 1987; Revised January 22, 1988)

\begin{abstract}
We determined fault plane solutions and focal depths for seven events which occurred in the Japan trench outer slope, using comparison between synthetic and observed long- and short-period teleseismic seismograms. The five normal fault solutions obtained in this study have nearly vertical nodal planes parallel to the trench and their depth range, $2-16 \mathrm{~km}$ below the seafloor, is in accord with bending of the oceanic lithosphere prior to subduction. The occurrence of both types of normal faulting, downthrow of both the continental and oceanic sides, is likely to be associated with the formation of horst-graben structures in the outer trench slope near the trench axis.

One normal fault solution ( $31 \mathrm{~km}$ below the seafloor) that is significantly deeper than the other normal fault solutions has a nearly vertical nodal plane striking parallel to the ENE magnetic anomaly lineations in the region. This event is also characterized by its lower stress drop or slower rupture than the other events. This event would represent a reactivation of the initial structural fabric inherited from the accretion at the mid-oceanic ridge and indicates that the bending stress is small at this depth. One reverse fault solution, $41 \mathrm{~km}$ below the seafloor, is in accord with the compressional bending stress in the deeper portion of the lithosphere. These events indicate that a neutral surface of bending stress is around $30 \mathrm{~km}$ depth in this region at least for the past few decades, consistent with the elastic thickness of lithosphere in adjacent regions. This implies that the lithosphere is not entirely in deviatoric tension in this region, suggesting that the 1933 Sanriku earthquake may be a large bending event.
\end{abstract}

\section{Introduction}

The purpose of this study is to determine accurately the focal depths and mechanisms of earthquakes which occurred at the Japan trench outer slope and to elucidate the faulting pattern caused by moderate-size earthquakes at this trench.

1 Now at C. F. Richter Lab, Earth Sci. Board, University of California, Santa Cruz, CA 95064, U.S.A. 
Such accurate focal depths are very important for analyses of the mechanics of earthquakes at the trench-outer rise area, which may be due to bending or lithospheric faulting of subducting plate. Such analyses also provide important information on the rheological properties of subducting lithosphere (e.g., CHAPPLE and Forsyth, 1979; Forsyth, 1980; Bodine et al., 1981).

The focal depths of offshore earthquakes in island arcs reported by ISC Bulletins have proved to be unreliable either because the hypocenters are located outside local seismic networks or due to anomalous velocity structure beneath island arcs. Even if the depths rely on the identification of the pP phase, they are often inaccurate because misidentification of this phase with pwP or other depth phases is common (YosHII, $1979 \mathrm{a}$; FORSYTH, 1982). The incorrect depths may lead to incorrect calculation of the take-off angles to local stations and thus result in incorrect fault plane solutions (SENO and KROEGER, 1983). Therefore, previous studies of trench-outer rise events (HERMANN, 1976; CHEN and Forsyth, 1978; FITCH et al., 1981; STEIN et al., 1982; Forsyth, 1982; CHINN and IsACKS, 1983; WARD, 1983; CHRISTENSEN and RUFF, 1987) have emphasized that these events must be studied individually using waveform analysis. In this study, we determined focal depths and fault plane solutions by comparison of synthetic and observed seismograms of WWSSN long- and short-period P waves. We also estimate the stress drop of each event to see whether there is any difference between mechanism types or depths.

Since the stress system within a subducting plate at the trench may vary from one arc to another arc or even within one arc (e.g., WATTS and TALWANI, 1974; CHAPPLE and Forsyth, 1979; WARD, 1983), it is important to study trench events along a single arc systematically and compare the results with other arcs. The Japan trench is suitable for such studies because the epicentral locations of offshore earthquakes reported in the ISC Bulletins are fairly good (errors $\$ 20-30 \mathrm{~km}$; UTsU, 1975; BARAZANGI and ISACKS, 1979; ICHIKAWA, 1979). In this trench, previous studies have so far established the thrust zone extending down to the depth of $60 \mathrm{~km}$ (Yoshin, 1975; Seno and Pongsawat, 1981; KawaKatsu and Seno, 1983) and the double seismic zone within the subducting slab at intermediate depth (HASEGAWA et al., 1978; YOSHII, 1979 a; BARAZANGI and ISACKS, 1979), which regionally overlaps with the thrust zone at its upper end (SENO and PONGSAWAT, 1981; KAWAKATSU and SENO, 1983). Between the thrust zone and the trench axis, the level of seismic activity is low (e.g., Hirata et al., 1983; NaGumo et al., 1984). Some events in this area, which were previously thought to be normal faults (YosHII, $1979 \mathrm{a}$ ), are proved to be thrust events (SENO and KROEGER, 1983). However, seismological studies for the area near and seaward of the trench axis have been scarce.

The large normal fault earthquake which occurred in 1933 at the northern part of the trench (KANAMORI, 1971) has been the subject of considerable discussion. KANAMORI (1971) proposed that this event faulted through the entire thickness of the lithosphere. This conclusion has been challenged by CHAPPLE and FORSYTH (1979) who believe that this large event, like the smaller events in the area, was also 
caused by the bending of the lithosphere. It is therefore of interest to study recent earthquakes to determine the stress state of the lithosphere in this portion of the trench. It is also of interest to compare the depth distribution of the teleseismic earthquakes with that of the microseismicity revealed by recent Ocean Bottom Seismometer (OBS) surveys (KasAHARA et al., 1982; Hirata et al., 1983; NAGUMO et al., 1984).

In the outer slope of the Japan trench, extensional features are shown by depthsounding and seismic reflection profiles. The outer trench wall is cut by steep scarps with throws of a few hundred meters; they are parallel to the trench strike and constitute a horst-graben structure (LuDwIG et al., 1966; TAMAKI et al., 1977; Iwabuchi, 1980; Shipboard Scientific Party, 1980; Kobayashi et al., 1987; CADET et al., 1987). This structure is believed to be a surface expression of normal faulting caused by bending of the plate before it enters the subduction zone (e.g., JONES et al., 1978). In addition to these normal faults, reactivated ancient normal faults trending parallel to the ENE oceanic magnetic anomalies are found (CADET $e t$ al., 1987). Also, an outer rise observed in this trench has been used to derive the elastic thickness of the lithosphere (JONES et al., 1978). It is therefore of interest to compare the faulting caused by earthquakes with the surface structure of the outer trench slope and the effective elastic thickness of the lithosphere. YosHII (1979c, 1981) noted that downthrow of both continental and oceanic sides occurred almost simultaneously at the trench axis around $39.7^{\circ} \mathrm{N}$ during the swarm activity in August 1969. This activity includes three major earthquakes with $m_{\mathrm{b}} \geq 5.0$. This study includes these earthquakes and other major earthquakes in the outer slope area of this trench.

\section{Method of Analysis}

We selected eight events which occurred from 1964 through 1978 with $m_{\mathrm{b}} \geq 5.0$ along the Japan trench from ISC Bulletins. However, two of these events had seismogram amplitudes too small for study. One event with $m_{\mathrm{b}}=4.7$ is included in the study because YosHII (1979c) obtained a reverse fault solution for this event. Hence, we analyzed seven events in total. The hypocentral parameters are listed in Table 1 and the epicenters are shown in Fig. 1. The epicentral locations of events 2-4 are taken from YosHI's (1981) relocation; others are from ISC Bulletins. The depths listed in Table 1 are ISC routinely determined depths, depths from pP-P reported by ISC and depths from pP-P corrected for the water layer by assuming that the pP phase reported by ISC is actually a pwP phase (see YosHII, 1979a).

We computed the synthetic seismograms using a program by KROEGER and GELLER (1986), which includes all reflections and conversions from an assumed crustal structure near the source. We used the crustal structure obtained by refraction surveys across the Japan trench along $40^{\circ} 40^{\prime} \mathrm{N}$ (Ludwig et al., 1966; MuRAUCHI et al., 1977). The crustal structure used for each event varies depending on its distance from the trench axis, and is listed in Table 2. The structure used may 


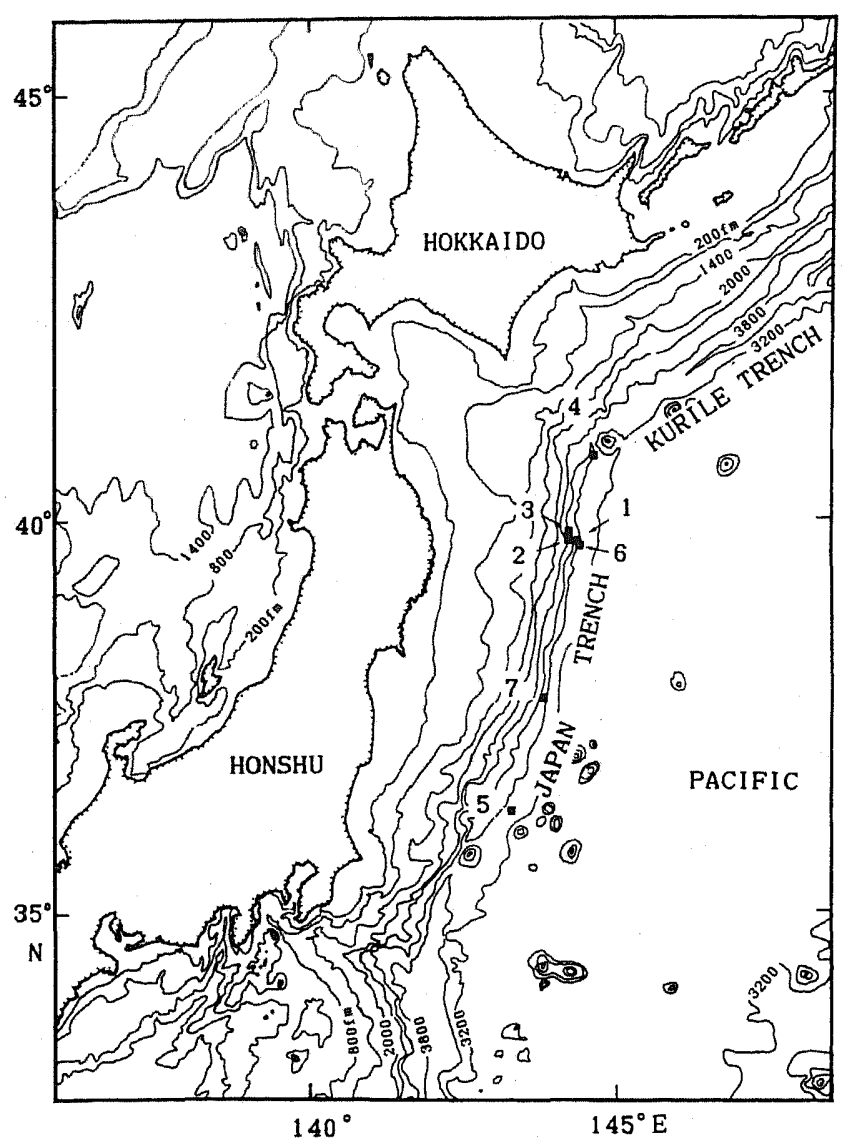

Fig. 1. Epicentral locations of the study events. The bathymetry is from CHASE and Menard (1969).

Table 1. Earthquakes analyzed.

\begin{tabular}{|c|c|c|c|c|c|c|c|c|c|c|}
\hline \multirow{2}{*}{ Event No. } & \multicolumn{4}{|c|}{ Date } & \multicolumn{2}{|c|}{ Location } & \multirow[b]{2}{*}{$m_{\mathrm{b}}$} & \multicolumn{3}{|c|}{ Depth-ISC } \\
\hline & $\mathrm{Y}$ & M & $\mathrm{D}$ & $\mathrm{H}$ & ${ }^{\circ} \mathrm{N}$ & $E$ & & $(\mathrm{~km})$ & $\begin{array}{l}(\mathrm{km}) \\
\mathrm{pP}-\mathrm{P}\end{array}$ & $\begin{array}{c}(\mathrm{km}) \\
\text { pwP-P }\end{array}$ \\
\hline 1 & 69 & 08 & 23 & 02 & 39.70 & 144.38 & 5.0 & - & 36 & 11 \\
\hline 2 & 69 & 08 & 23 & 06 & 39.72 & 144.29 & 5.2 & - & 38 & 13 \\
\hline 3 & 69 & 08 & 24 & 22 & 39.80 & 144.30 & 5.2 & - & 89 & 62 \\
\hline 4 & 69 & 12 & 04 & 08 & 40.74 & 144.69 & 5.6 & 14 & 17. & 0 \\
\hline 5 & 75 & 06 & 14 & 23 & 36.31 & 143.30 & 6.0 & - & 42 & 19 \\
\hline 6 & 78 & 04 & 05 & 07 & 39.64 & 144.46 & 5.3 & 31 & 31 & 7 \\
\hline 7 & 67 & 07 & 08 & 19 & 37.74 & 143.88 & 4.7 & 41 & 67 & 41 \\
\hline
\end{tabular}

Epicenters are from the ISC Bulletins except for Events 1-3 for which we used YosHII's (1981) relocation. pwP-P depth is calculated on the assumption that pP phase of the bulletins are pwP (see YosHII, 1979 a). 
Table 2. Crustal structure used in this study.

\begin{tabular}{|c|c|c|c|c|}
\hline Event & $\begin{array}{c}V_{\mathrm{P}} \\
(\mathrm{km} / \mathrm{s})\end{array}$ & $\begin{array}{c}V_{\mathrm{S}}^{*} \\
(\mathrm{~km} / \mathrm{s})\end{array}$ & $\begin{array}{l}\text { Density } \\
\left(\mathrm{g} / \mathrm{cm}^{3}\right)\end{array}$ & $\begin{array}{c}\text { Thickness } \\
(\mathrm{km})\end{array}$ \\
\hline 1 & 1.52 & 0.0 & 1.0 & 7.1 \\
\hline & 2.3 & 1.3 & 2.0 & 0.7 \\
\hline & 4.7 & 2.7 & 2.5 & 2.0 \\
\hline & 6.6 & 3.8 & 2.8 & 7.3 \\
\hline & 8.0 & 4.6 & 3.3 & - \\
\hline \multirow[t]{5}{*}{2} & 1.52 & 0.0 & 1.0 & 6.9 \\
\hline & 2.5 & 1.44 & 2.0 & 0.8 \\
\hline & 4.4 & 2.54 & 2.5 & 2.2 \\
\hline & 6.7 & 3.9 & 2.8 & 8.2 \\
\hline & 8.0 & 4.6 & 3.3 & - \\
\hline \multirow[t]{5}{*}{3} & 1.52 & 0.0 & 1.0 & 6.9 \\
\hline & 2.5 & 1.44 & 2.0 & 0.8 \\
\hline & 4.4 & 2.54 & 2.5 & 2.2 \\
\hline & 6.7 & 3.9 & 2.8 & 8.2 \\
\hline & 8.0 & 4.6 & 3.3 & - \\
\hline \multirow[t]{5}{*}{4} & 1.52 & 0.0 & 1.0 & 6.6 \\
\hline & 2.3 & 1.3 & 2.0 & 0.7 \\
\hline & 4.7 & 2.7 & 2.5 & 2.0 \\
\hline & 6.6 & 3.8 & 2.8 & 7.0 \\
\hline & 8.0 & 4.6 & 3.3 & - \\
\hline \multirow[t]{5}{*}{5} & 1.52 & 0.0 & 1.0 & 6.4 \\
\hline & 2.3 & 1.3 & 2.0 & 0.7 \\
\hline & 4.7 & 2.7 & 2.5 & 1.7 \\
\hline & 6.6 & 3.8 & 2.8 & 5.4 \\
\hline & 8.0 & 4.6 & 3.3 & - \\
\hline \multirow[t]{5}{*}{6} & 1.52 & 0.0 & 1.0 & 6.6 \\
\hline & 2.3 & 1.3 & 2.0 & 0.7 \\
\hline & 4.7 & 2.7 & 2.5 & 2.0 \\
\hline & 6.6 & 3.8 & 2.8 & 7.0 \\
\hline & 8.0 & 4.6 & 3.3 & - \\
\hline \multirow[t]{5}{*}{7} & 1.52 & 0.0 & 1.0 & 7.1 \\
\hline & 2.3 & 1.3 & 2.0 & 0.7 \\
\hline & 4.7 & 2.7 & 2.5 & 2.0 \\
\hline & 6.6 & 3.8 & 2.8 & 7.0 \\
\hline & 8.0 & 4.6 & 3.3 & - \\
\hline
\end{tabular}

$* V_{\mathrm{P}} / V_{\mathrm{S}}$ is assumed to be 1.73 . The crustal structure is based on the refraction surveys by Ludwig et al. (1966) and Murauchi et al. (1977) (see Fig. 3).

not be appropriate because of the errors in epicentral locations. However, the errors should not exceed a few tens of kilometers (UTSU, 1975; ICHIKAWA, 1979), and thus do not affect the results obtained.

The computation was done only for stations in the epicentral distance range $30^{\circ}-90^{\circ}$ to avoid the effect of the upper mantle. The source is assumed to be a double couple point source. The far-field source time function is assumed to be trapezoidal and uniform for all stations for each particular event. This is appro- 
priate because the size of the events is not large $\left(M_{\mathrm{s}}<6.0\right)$. Also the trade-off between the source time function and the focal depth is not serious for this size of events (STEIN and WiENS, 1986) as will be shown later. The pulses, which include all effective depth phases such as pP, sP, pwP, swP, pwwP ... are convolved with the instrument response of WWSSN seismographs, the far-field source time function, the $Q$ operator for attenuation (CARPENTER, 1966) in which $T_{\mathrm{p}}^{*}$ of $1 \mathrm{~s}$ is assumed. To derive the seismic moment, the geometrical spreading factor is calculated from Herrin's (1968) table assuming $V_{\mathrm{p}}=6.0 \mathrm{~km} / \mathrm{s}$ and $\rho=2.7 \mathrm{~g} / \mathrm{cm}^{3}$ at stations. The time constants of the source time function, $t_{0}, t_{1}$, and $t_{2}$ (see Fig. 8 for these), are obtained by the visual fit to the first half cycle of the waveform. Assuming that the rupture area is $\left(v t_{\mathrm{p}}\right)^{2}$, where $v$ is the rupture velocity and $t_{\mathrm{p}}=t_{0}+t_{1}$, we estimated the stress drop by

$$
\Delta \sigma=2.4 M_{\mathrm{o}} /\left(v t_{\mathrm{p}}\right)^{3}
$$

where $M_{\mathrm{o}}$ is the seismic moment from long-period records (KIKUCHI and FuKaO, 1987).

For each event, we obtained the focal mechanism solution using P-wave first motions and S-wave polarization angles read from WWSSN records. We then determined the focal depth and source time function by matching the waveform assuming this focal mechanism. In the case when the focal mechanism is not constrained well from the first motion data, we first obtained the rough estimate for focal depth and source time function using stations far from the nodal planes. We then examined the nodal planes by comparing synthetics with observed seismograms at stations near the nodes and obtained optimal solutions. Using this optimal solution, we redetermined the focal depth and the source time function. For four of the events (Events 1, 3, 5, and 7), YosHII (1979a,b,c) has obtained the mechanism solutions using WWSSN first motion data. We reexamined his solutions and modified them except for Event 7, for which the available data are scarce and we used his mechanism solution.

\section{Results}

We list the source parameters obtained in this study in Table 3, and the depth, source time function, seismic moment, and stress drop in Table 4. We also list the number of stations used and the standard deviation of the best-fit depths among stations in Table 4. Figure 2 shows the fault plane solutions in the bathymetric map (Chase and Menard, 1969). Figure 3 shows the foci and the sense of fault motion projected on the crustal structure in an E-W section of the Japan trench at $40^{\circ} 40^{\prime} \mathrm{N}$ (MURAUCHI et al,, 1977; LUDWIG et al., 1966), taking the vertical nodal planes as fault planes.

Events 1-6 have normal or vertical fault solutions, Event 7 a reverse fault solution. The steeper nodal planes of the normal fault events are almost parallel to the trend of the Japan trench except Event 6. For Events 1-5, we interpret these 
Table 3. Source parameters of the earthquakes obtained in this study.

\begin{tabular}{|c|c|c|c|c|c|c|c|c|c|c|}
\hline \multirow{2}{*}{ Event } & \multirow{2}{*}{ Date } & \multirow{2}{*}{$\begin{array}{c}\text { Strike } \\
\text { AZ } \\
\left(N^{*} E\right)\end{array}$} & \multirow{2}{*}{$\begin{array}{l}\text { Dip } \\
\text { () }\end{array}$} & \multirow{2}{*}{$\begin{array}{l}\text { Slip } \\
\text { angle } \\
\left.()^{\circ}\right)\end{array}$} & \multicolumn{2}{|c|}{ Aux. plane } & \multicolumn{2}{|c|}{$P$-axis } & \multicolumn{2}{|c|}{$T$-axis } \\
\hline & & & & & $\begin{array}{l}\text { Dip dir. } \\
\left(N^{2} E\right)\end{array}$ & $\begin{array}{l}\text { Dip } \\
\text { (") }\end{array}$ & $\mathrm{AZ}$ & $\mathrm{PL}$ & $\mathrm{AZ}$ & PL \\
\hline 1 & $\begin{array}{llll}69 & 08 & 23 & 02\end{array}$ & 168 & 76 & -90 & 78 & 14 & 78 & 59 & 258 & 31 \\
\hline 2 & $\begin{array}{llll}69 & 08 & 23 & 06\end{array}$ & 359 & 68 & -90 & 269 & 22 & 269 & 67 & 89 & 23 \\
\hline 3 & $\begin{array}{lll}69 & 08 & 24\end{array}$ & 5 & 90 & -90 & 180 & 0 & 275 & 45 & 95 & 45 \\
\hline 4 & $\begin{array}{lll}69 & 1204\end{array}$ & 345 & 70 & -140 & 329 & 53 & 208 & 42 & 108 & 11 \\
\hline 5 & $\begin{array}{lll}75 & 06 & 14\end{array}$ & 184 & 55 & -126 & 146 & 48 & 35 & 61 & 299 & 4 \\
\hline 6 & $\begin{array}{lll}78 & 04 & 05\end{array}$ & 244 & 70 & -102 & 186 & 23 & 135 & 63 & 343 & 24 \\
\hline 7 & 670708 & 200 & 45 & 90 & 110 & 45 & 110 & 0 & - & 90 \\
\hline
\end{tabular}

Mechanism solution of Event 7 is from YosHII (1979c). AZ and PL denote azimuth and plunge, respectively.

Table 4. Depth and source time function for the study events.

\begin{tabular}{|c|c|c|c|c|c|c|c|c|c|c|}
\hline \multirow{3}{*}{ Event } & \multirow{3}{*}{$\begin{array}{c}\text { Depth } \\
(\mathrm{km})\end{array}$} & \multirow{3}{*}{$\begin{array}{c}\text { Depth } \\
\text { below } \\
\text { seafloor } \\
(\mathrm{km})\end{array}$} & \multirow{3}{*}{$\begin{array}{l}\text { S.D. and } \\
\text { number of } \\
\text { stations } \\
(\mathrm{km})\end{array}$} & \multicolumn{5}{|c|}{ Source time function } & \multirow{3}{*}{$\begin{array}{c}M_{\mathrm{o}} \\
\left(10^{23}\right. \\
\text { dyn-cm) }\end{array}$} & \multirow{3}{*}{$\begin{array}{c}\Delta \sigma \\
\text { (bar) }\end{array}$} \\
\hline & & & & \multicolumn{3}{|c|}{ LP } & \multicolumn{2}{|c|}{ SP } & & \\
\hline & & & & $T_{0}$ & $\begin{array}{l}T_{1} \\
\text { (s) }\end{array}$ & $T_{2}$ & & $T_{2}$ & & \\
\hline 1 & 9 & 2 & $0.9(6)$ & - & - & - & 0.5 & 0.5 & - & - \\
\hline 2 & 12 & 5 & $1.3(8)$ & 0.5 & 1.0 & 0.5 & 0.5 & 0.5 & 7 & 18 \\
\hline 3 & 11 & 4 & $1.8(8)$ & 0.5 & 0.5 & 0.5 & 0.5 & 0.5 & 18 & 160 \\
\hline 4 & 21 & 14 & $1.5(8)$ & 0.5 & 1.0 & 0.5 & 0.3 & 0.3 & 26 & 68 \\
\hline 5 & 22 & 16 & $2.5(9)$ & 0.5 & 1.0 & 2.0 & - & - & 104 & 274 \\
\hline 6 & 38 & 31 & $5.3(8)$ & 2.0 & 2.0 & 2.0 & 0.8 & 0.8 & 53 & 7 \\
\hline 7 & 48 & 41 & $1.3(6)$ & 0.5 & 1.0 & 0.5 & 0.1 & 0.1 & 10 & 263 \\
\hline
\end{tabular}

S.D. denotes standard deviation in the depth determination. The number in parentheses in the S.D. column is the number of stations used for the depth determination. $T_{0}, T_{1}, T_{2}$ are the time constants describing the trapezoidal source time function (see Fig. 8). LP and SP denote long-period and short-period. $T_{1}$ is always assumed to be 0 for SP.

planes as their fault planes because normal faults usually have planes dipping more steeply than $45^{\circ}$ (JAEGER and COOK, 1979). Assuming this, the fault motion of Events 1 and 5 shows downthrow of the arc-side and that of Events 2-4 shows downthrow of the ocean-side (Figs. 2 and 3).

Events $1-3$, having depths of $2-5 \mathrm{~km}$ below the seafloor, are located in the crust (oceanic second and third layers) and Events 4 and 5, having depths of 14 and $16 \mathrm{~km}$ below the seafloor, are in the upper mantle (Fig. 3). Events 6 and 7 have depths of 31 and $41 \mathrm{~km}$ below the seafloor. The stress drops are on the order of tens to hundreds of bars, which are typical of intraplate earthquakes in subduction zones (FUKAO and KIKUCHI, 1987); however, Event 6 has a small stress drop of 


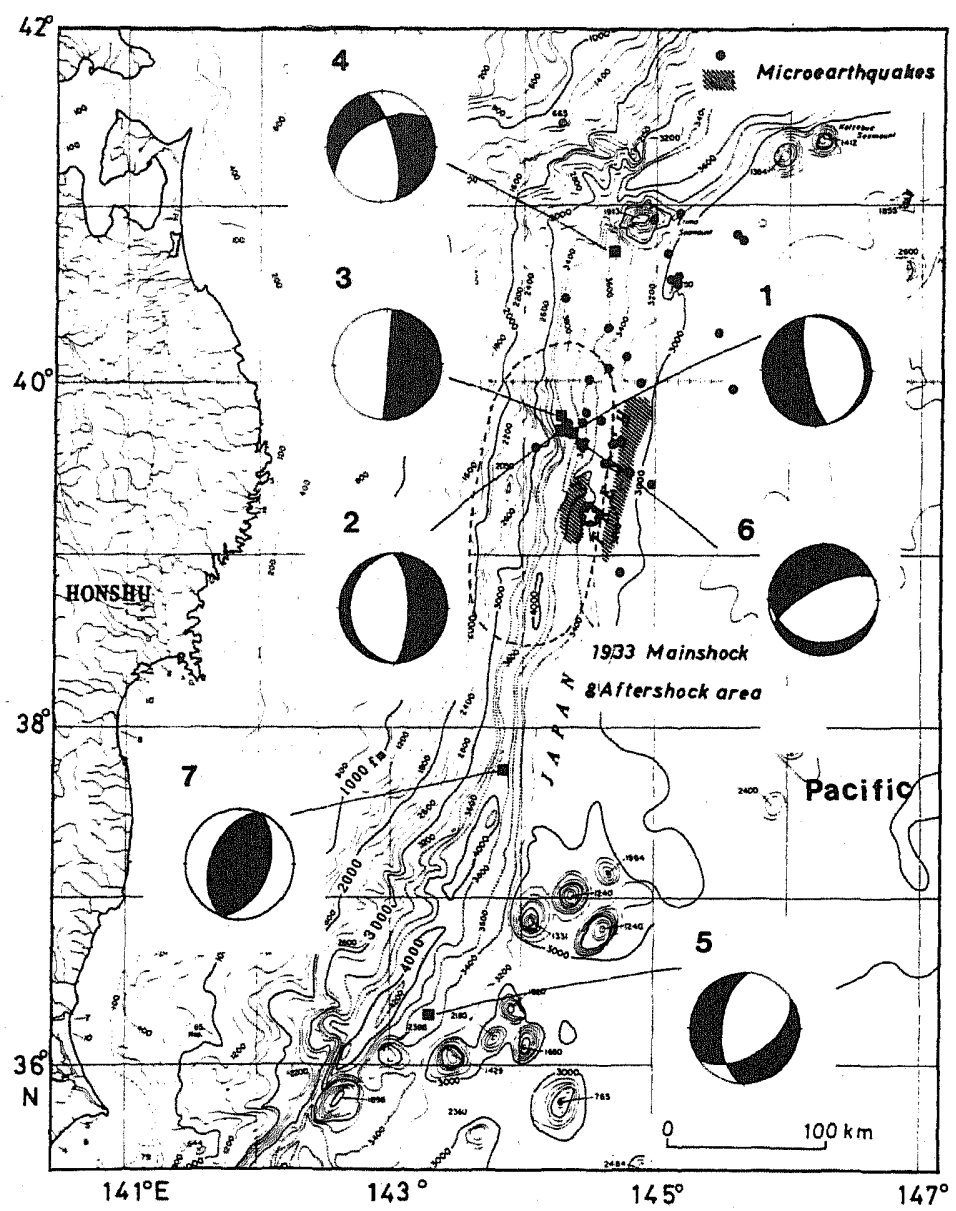

Fig. 2. The mechanism solutions obtained in this study (equal area plot of the lower hemisphere) plotted in the bathymetric map off northern Honshu (CHASE and MENARD, 1969). The number attached with each mechanism solution is the event number in Table 1. The mainshock and aftershock area of the 1933 Sanriku earthquake $\left(M_{\mathrm{w}}=8.4\right)$ are indicated by the star and broken line, respectively (KANAMORI, 1971). The shaded area and the small solid circles are the microearthquake activity revealed by the OBS surveys in the northern part of the Japan trench (shaded: NaGumo et al., 1984; solid circle: Hirata et al., 1983).

7 bar. The details for each particular event are described as follows.

\subsection{Event 1 (196908 $\left.230254, m_{b}=5.0\right)$}

As this event has a small magnitude, only short-period records are available for this event, but nevertheless the strike of the more vertical nodal plane is roughly constrained from P-wave polarities and S-wave polarization angles (Fig. 4). The 


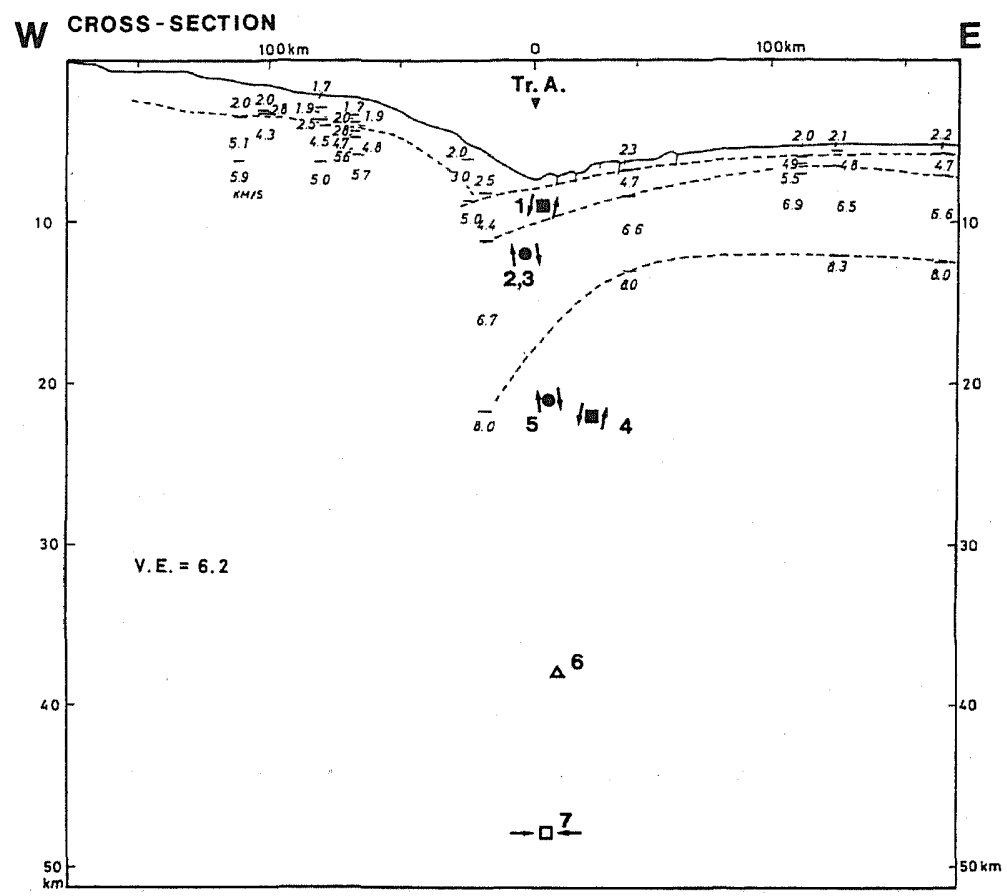

Fig. 3. The foci obtained in this study in a vertical E-W section of the crustal structure off northern Honshu (MURAUCHI et al., 1977; LUDwig et al., 1966). The sense of faulting is indicated by the arrows for the normal fault events (1-5). The $\mathrm{P}$-axis is indicated by the arrows for Event 7 . The small number in the crustal section is the P-wave velocity $(\mathrm{km} / \mathrm{s})$.

auxiliary plane is, however, not constrained; we assumed a pure dip-slip fault for this case. Figure 5 shows a comparison of the synthetics for various source depths with the observed SP seismogram at ALQ, using the above mechanism solution. In Fig. 5, predicted arrivals of pP, pwP, pwwP are indicated in one of the synthetics. As the assumed depth increases, these phases arrive later. If the depth is larger than $10 \mathrm{~km}$, the synthetic waveform following the P-wave onset is much simpler than observed. In contrast, the synthetic waveform calculated for $10 \mathrm{~km}$ depth shows seafloor reflections which can match the observed complexity. At this depth pwP should be the largest later phase and can explain the large phase arriving about $12 \mathrm{~s}$ after the P-wave onset.

We determined the best-fit depths for the SP records of the study events by calculating synthetics at every $1 \mathrm{~km}$ source depth and comparing them with the observed seismograms. In Fig. 4, synthetics at various stations are compared with the observed records, with the best-fit source depth used for the synthetics indicated below at each station code. 


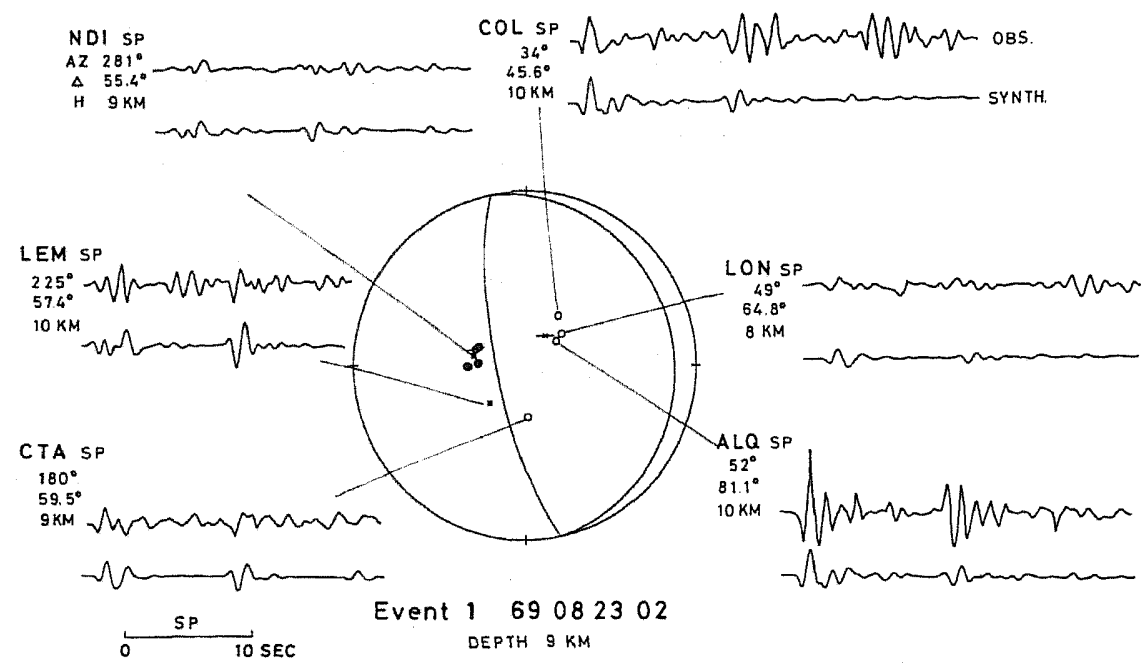

Fig. 4. A mechanism diagram and a comparison of the synthetics with the observed P-wave records for Event 1. In the following figures, the mechanism plot is the equal area projection of the lower hemisphere. Large and small open circles are dilatational LP and SP P-wave first motions, respectively. Small solid circles are compressional SP P-wave first motions. Crosses are the uncertain readings and asterisks indicate nodal polarities. Arrows indicate Swave polarization angles. Nodal lines are those listed in Table 3 . The azimuth of the station, epicentral distance, and the depth used for the calculation of the synthetics shown in the figure are indicated below the station code.

\subsection{Event $2\left(196908230639, m_{b}=5.2\right)$}

The strike of the more vertical nodal plane was constrained by $\mathrm{P}$-wave polarities and $\mathrm{S}$-wave polarization angles from stations in the northeast quadrant (Fig. 6). The small amplitude of the P-wave onset at these stations (e.g., LON and AAM) shows that they are close to the node. Since the auxiliary nodal plane cannot be fixed, we assumed a pure dip-slip fault for this case too.

Figure 7 shows the synthetic SP waveforms for various depths at LON using the above mechanism solution. Above the $12 \mathrm{~km}$ depth synthetics, the calculated pulses before convolution with the instrument response, source time function and attenuation operator are presented. The largest later phase in the synthetics is pwP. As the depth increases, the P-wave onset becomes hard to see, because the station is close to the node. Comparison of the waveforms following the onset clearly shows that the best-fit source depth for this station is around $12 \mathrm{~km}$. In the observed record, we can identify pwP, pwwP, and possibly pwwwP phases.

Figure 8 shows an example for the determination of source time function and depth using a LP record. The synthetics for three different source time functions at three different depths are compared with the observed LP record (dotted lines in Fig. 8) at KBL. This figure shows that the source time function can be constrained 


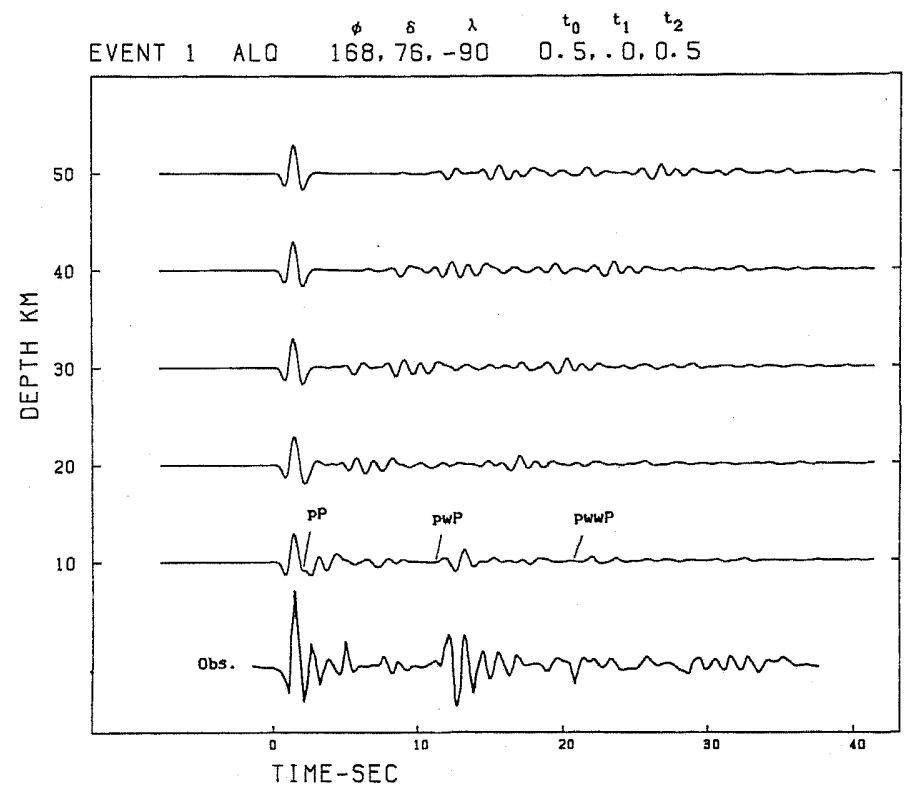

Fig. 5. A comparison of the synthetics for various depths with the observed SP record at ALQ for Event 1. At the top, the mechanism solution (strike, dip, and slip) and the source time function are shown. The observed record is best fitted by the synthetics at $10 \mathrm{~km}$ depth.

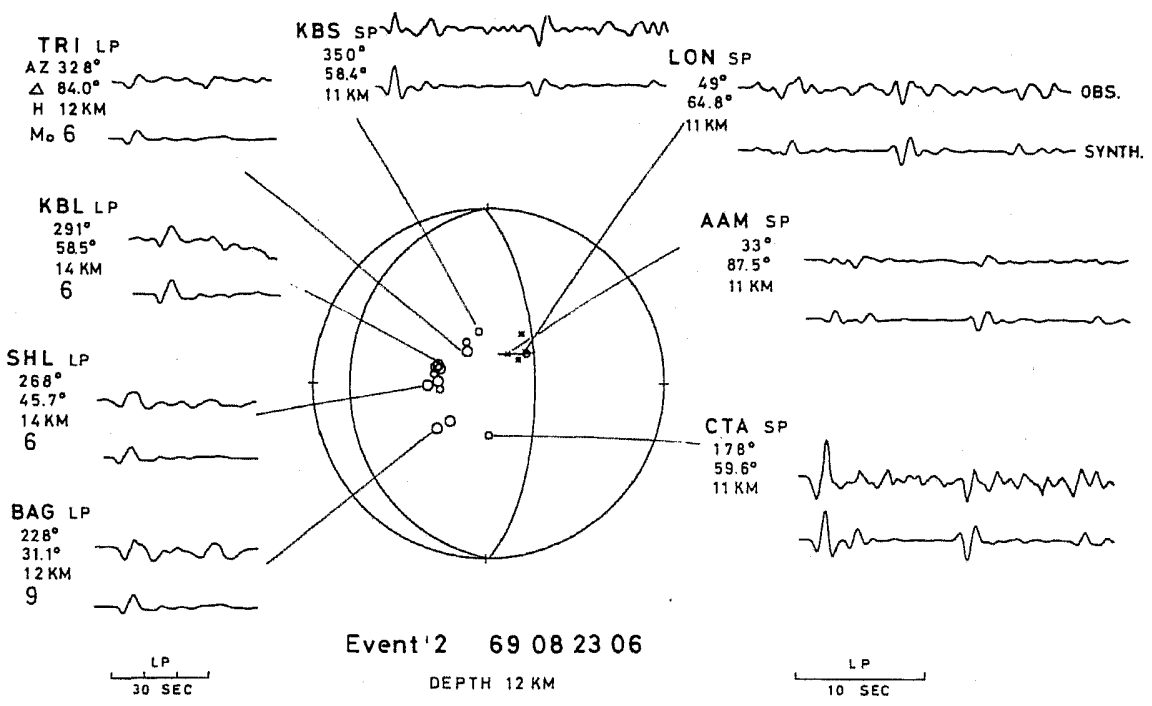

Fig. 6. A mechanism diagram and a comparison of the synthetics with the observed P-wave records for Event 2. The seismic moment used for the calculation of the synthetics shown in the figure is indicated below the depth of each event for LP records (unit: $10^{23}$ dyn-cm). Others are the same as in Fig. 4. 


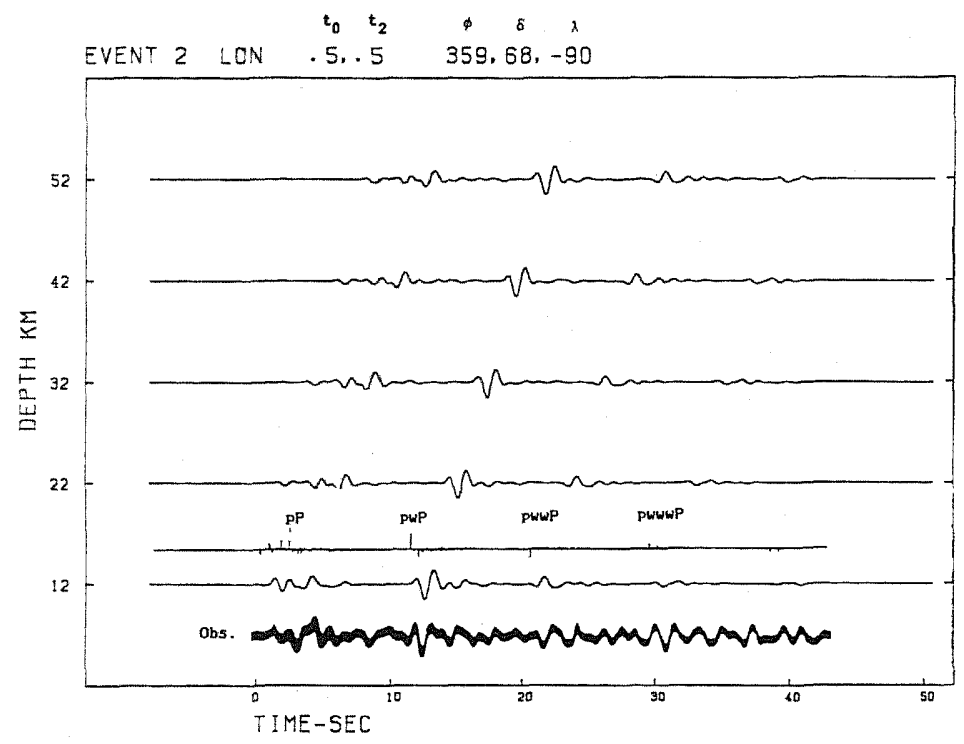

Fig. 7. A comparison of the synthetics for various depths with the observed SP record at LON for Event 2. The calculated pulses for $12 \mathrm{~km}$ depth are also shown above the synthetics at this depth. The observed record is best fitted by the synthetics at $12 \mathrm{~km}$.

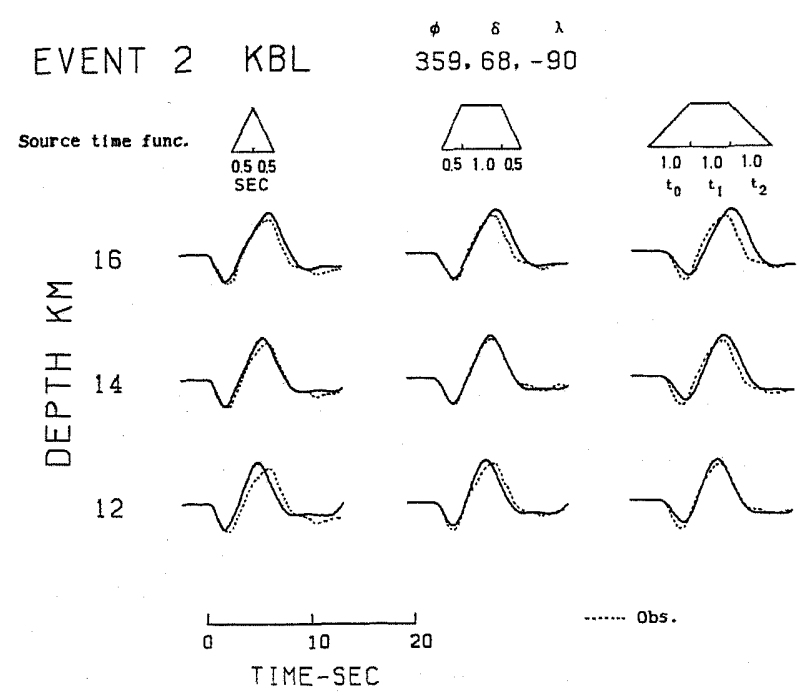

Fig. 8. Determination of the source time function at KBL for Event 2. The solid lines and dotted lines show the synthetic and observed seismograms, respectively. The source time function used for the synthetics is shown at the top. The source time function can be determined by the first half cycle of the waveform as the center of the figure. 
by the first half cycle of the waveform and the depth by the whole one cycle. Even if we use the source time functions with a marginal fit to the observed waveform (right and left of the figure), we can determine the depth within $2 \mathrm{~km}$ of the best-fit depth $(14 \mathrm{~km})$ from the correct source time function (center of the figure). This shows that the trade-off between the source time function and the source depth is not serious for the LP seismograms for this event; this is also true for all the other events treated in this study. For the depth determination from LP records in this study, we used a source time function determined from one station and then calculated the synthetics for other stations at every $2 \mathrm{~km}$ source depth to compare with the observed records.

In Fig. 6 it can be seen that the source depth derived from the SP records, which is completely free of the trade-off between the time function and the depth, is close to the best-fit depth from the LP records. For the LP records, the seismic moment used for the synthetics is indicated in a $10^{23}$ dyn- $\mathrm{cm}$ unit.

\subsection{Event $3\left(196908242203, m_{b}=5.2\right)$}

The strike and dip of the nearly vertical nodal plane are roughly constrained by the P-wave polarities (Fig. 9). We selected the optimal solution (Fig. 9) by comparison of the waveform at the stations near the node. The solution by YosHII (1979 c) has a SSW strike with a reverse fault component. His solution does not explain the polarities and waveforms at stations in the southwest quadrant. Using the above solution we compared the synthetics at various source depths with the observed records. Figure 10 shows an example at POO. A depth of about $10 \mathrm{~km}$ fits

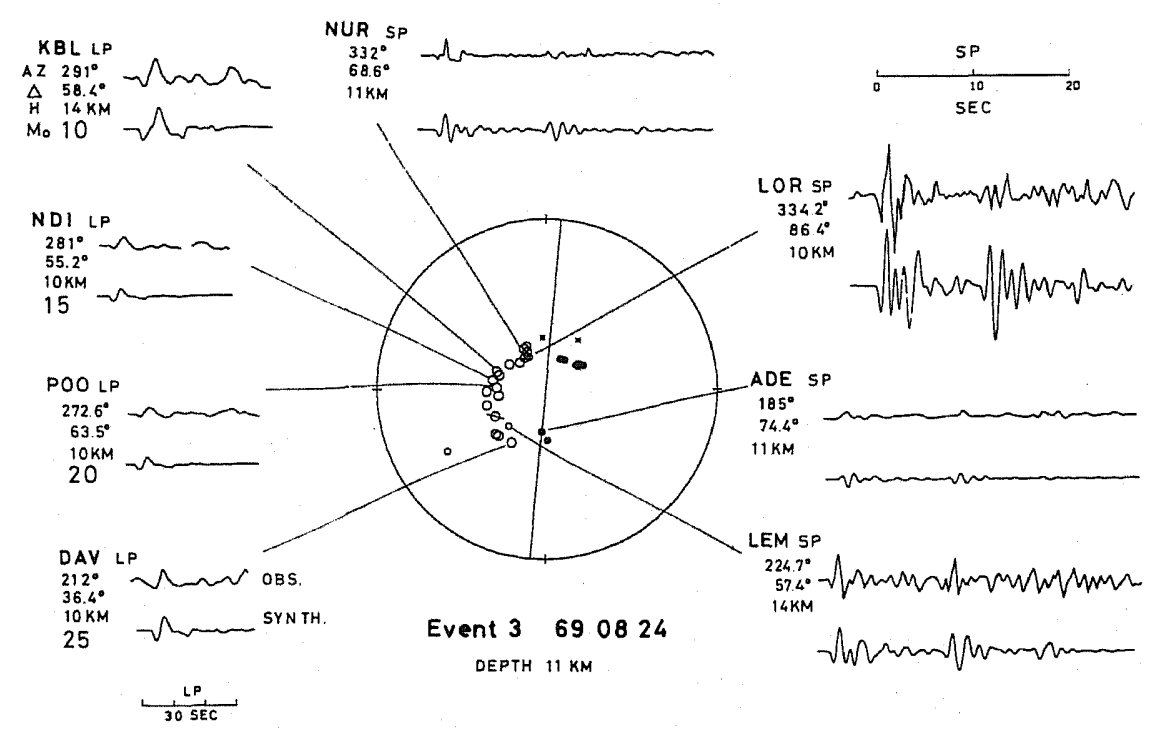

Fig. 9. A mechanism diagram and a comparison of the synthetics with the observed P-wave records for Event 3. 


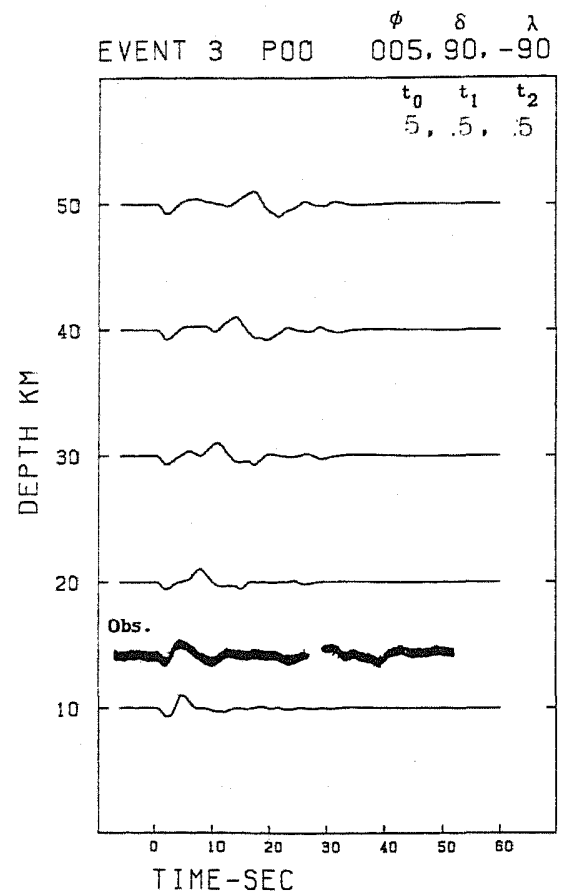

Fig. 10. A comparison of the synthetics for various depths at POO for Event 3. The observed record is best fitted by the synthetics at $10 \mathrm{~km}$ depth.

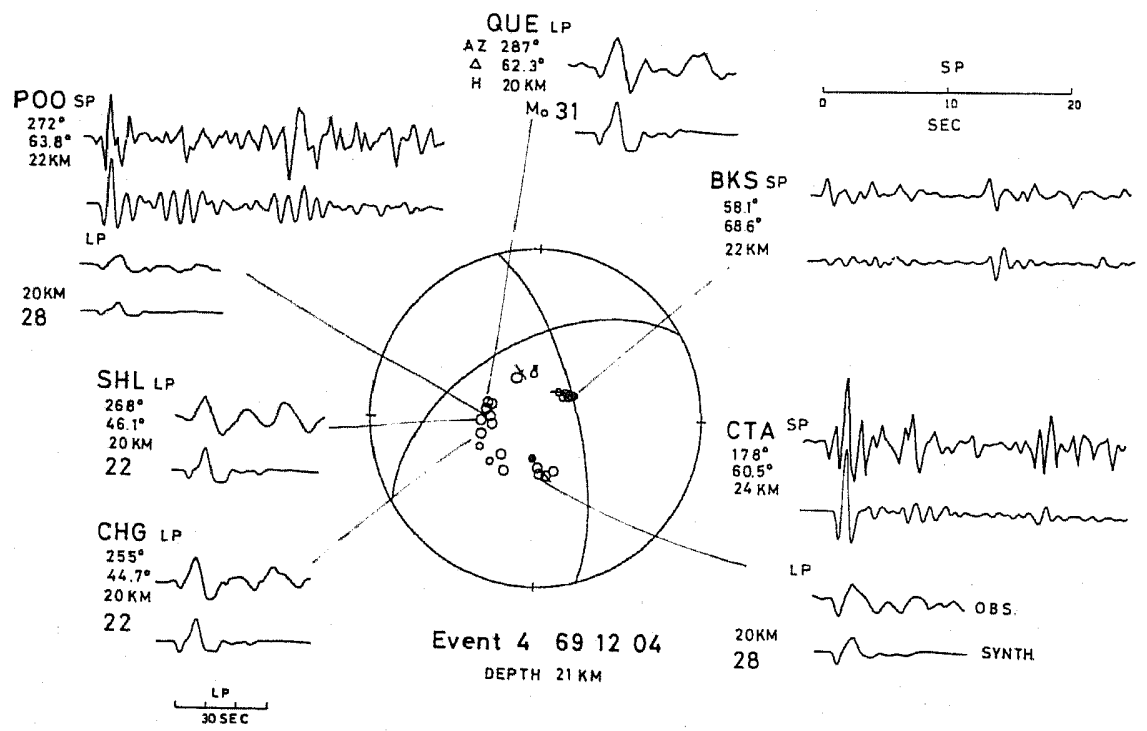

Fig. 11. A mechanism diagram and a comparison of the synthetics with the observed P-wave records for Event 4. 

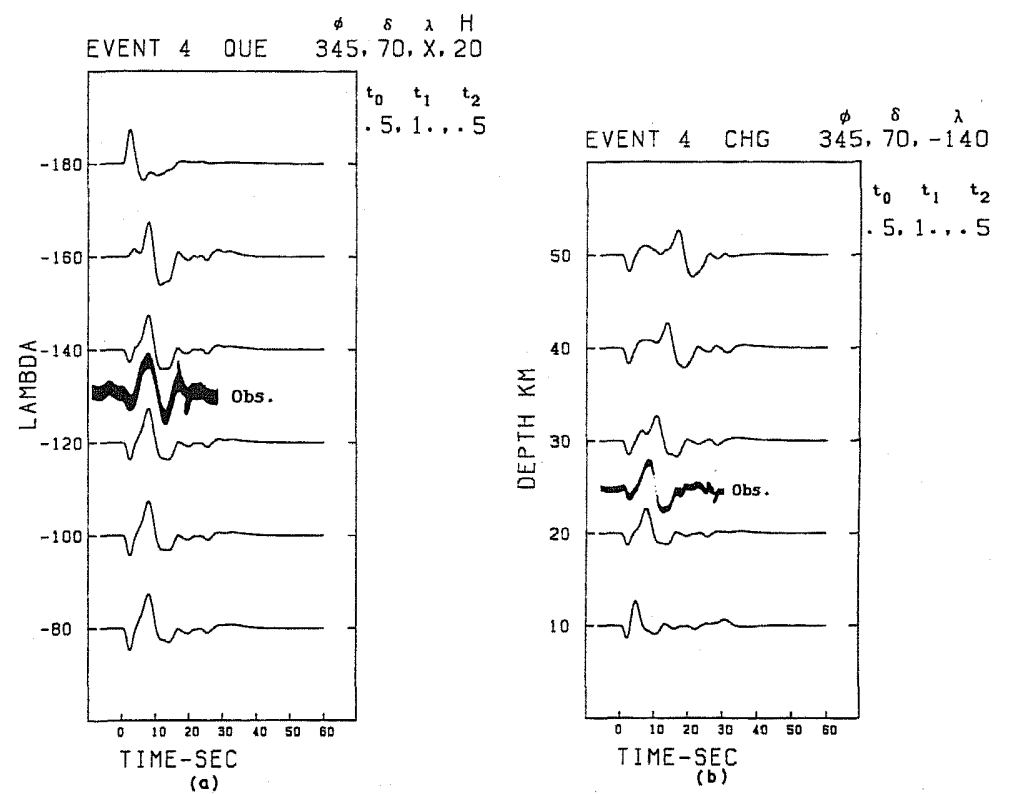

Fig. 12. (a) A comparison of the synthetics for various slip angles at QUE for Event 4. The observed record is best fitted by the synthetics at about $-140^{\circ}$ slip angle. (b) A comparison of the synthetics for various depths at $\mathrm{CHG}$ for Event 4 . The observed record is best fitted by the synthetics at $20 \mathrm{~km}$ depth.

the observed record. In Fig. 9, both the SP and LP records consistently provide the best-fit depths of about $10 \mathrm{~km}$.

\subsection{Event $4\left(19691204, m_{b}=5.6\right)$}

The more vertical plane dipping to the east is constrained by $\mathrm{P}$-wave polarities and a S-wave polarization angle at stations in the northwest quadrant (Fig. 11). Station QUE was then used to determine the best slip angle. Figure 12(a) shows a comparison of the synthetics for various slip angles at QUE with the observed Pwave record. The relative amplitude of the first half cycle to that of the second one constrained the slip angle of about $-140^{\circ}$. Figure 12(b) shows a comparison of the synthetics for various depths at $\mathrm{CHG}$ with the observed record using this mechanism solution. The synthetics at depth of about $20 \mathrm{~km}$ fit the observed record.

In Fig. 11, the amplitude of the later phase arriving $20 \mathrm{~s}$ after the $\mathrm{P}$-wave onset in the LP records is larger than calculated. This larger later phase is also seen in the LP records of Event 5 (Fig. 13). These two events are the largest among the shallow normal fault events in this study (Table 1). These later phases are probably not modeled by the ringing P-waves produced by the updip propagation of faulting beneath the trench (WARD, 1979) because the rupture size of these events estimated from the source time is around $5 \mathrm{~km}$ and thus their rupture would not have reached the seafloor. The P-wave reverberations not fully modeled are probably due to the 


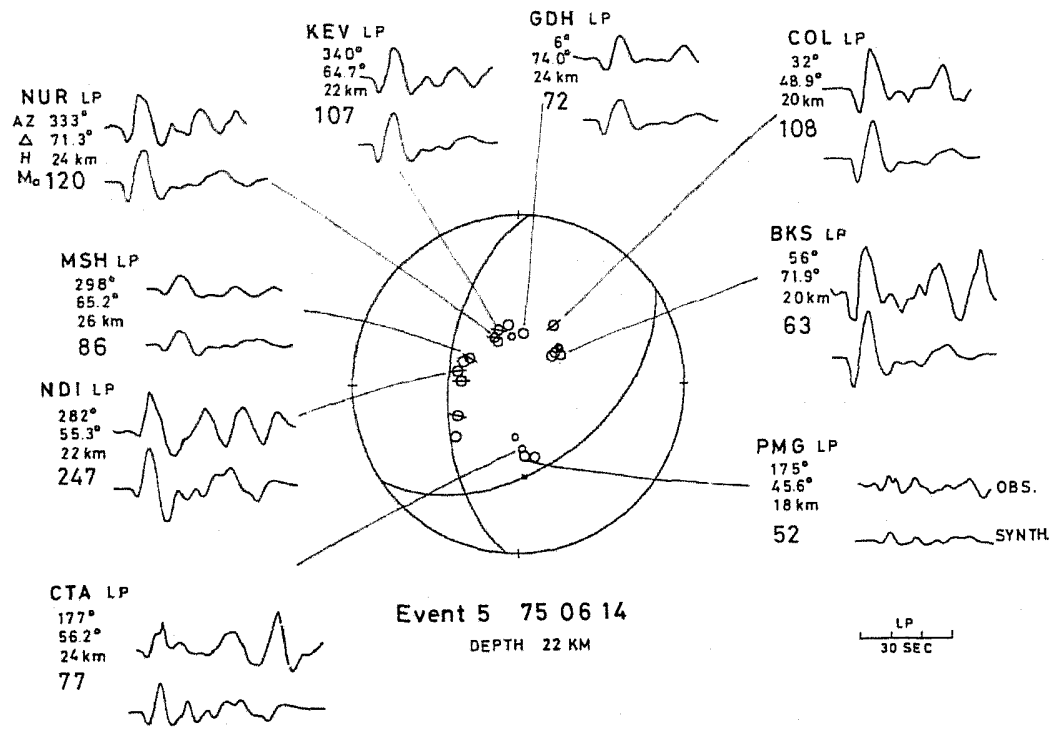

Fig. 13. A mechanism diagram and a comparison of the synthetics with the observed P-wave records for Event 5.

effect of the dipping seafloor on the water phase reflections (WIENS, 1987).

\subsection{Event $5\left(19750614, m_{b}=6.0\right)$}

The strike of the N-S trending nodal plane is well constrained by the S-wave polarization angles (Fig. 13). The dip angle of this plane was then determined as $55^{\circ}$ using the waveform comparison at the stations near the node. Then the best slip angle was determined as $-126^{\circ}$ using the LP record at CTA; Fig. 14(a) shows the comparison of the synthetics for various slip angles with the observed record at CTA.

Because this event is relatively large, the SP records are complex and not used for the depth determination. Figure 14(b) shows a comparison of the synthetics for various depths at $\mathrm{KEV}$ with the observed record using the above mechanism solution.

\subsection{Event $6\left(19780405, m_{b}=5.3\right)$}

Because of the limited P-wave polarity data, we supplemented them using those from local stations in Honshu and Hokkaido (small symbols at the circumference of the mechanism plot in Fig. 15). Two solutions are possible; one is the strike-slip solution (dotted lines in Fig. 15) and the other is the normal fault solution (solid lines in Fig. 15). It should be noted here that the calculated take-off angles to local stations are dependent on the assumed crustal structure and source depth. Fortunately, however, this does not affect the selection of solutions above because 

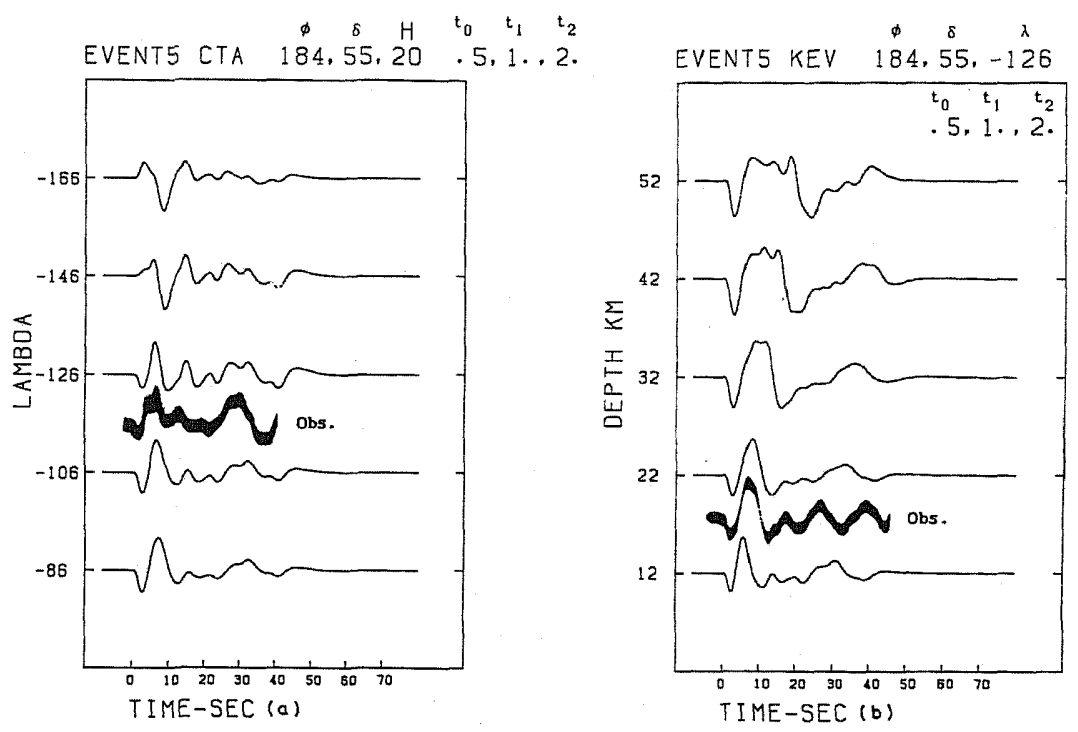

Fig. 14. (a) A comparison of the synthetics for various slip angles at CTA for Event 5 . The observed record is best fitted by the synthetics at about $-126^{\circ}$ slip angle. (b) A comparison of the synthetics for various depths at KEV for Event 5 . The observed record is best fitted by the synthetics at $22 \mathrm{~km}$ depth.

the source depth of this event is apparently in the uppermost mantle and thus the Pwave polarities from local stations only shift to the opposite position in the equal area net, if the depth becomes larger. In Fig. 16 we compared the synthetics for the two possible solutions with the observed LP record at SHL. The normal fault solution produces a fit at about $40 \mathrm{~km}$ depth (left in Fig. 16); in contrast, the strikeslip solution did not produce a fit at any depth. For the other stations, similarly, the normal fault solution produced a better fit than the strike-slip solution. Thus, we chose the normal fault solution for this event.

The deviation of the best-fit depth among stations for this event is large compared to the other events (Fig. 15). We calculated synthetics at every $5 \mathrm{~km}$ for the depth determination of this event. At some of the stations the fit of the synthetics to the observed records are poor (e.g., KTG, GDH, KBS, and HKC), indicating the solution obtained is still not satisfactory. However, we cannot doubt that this event has a different type of mechanism solution and depth from the other normal fault events. Also, note that the source time of this event is long compared with other events, and produced a lower stress drop than the other events (Table 4). Its rupture characteristics are somewhat different from those of the other normal fault events.

3.7 Event 7 (1967 $\left.0708, m_{b}=4.7\right)$

Because of the scarcity of the available polarity data, it is difficult to constrain 


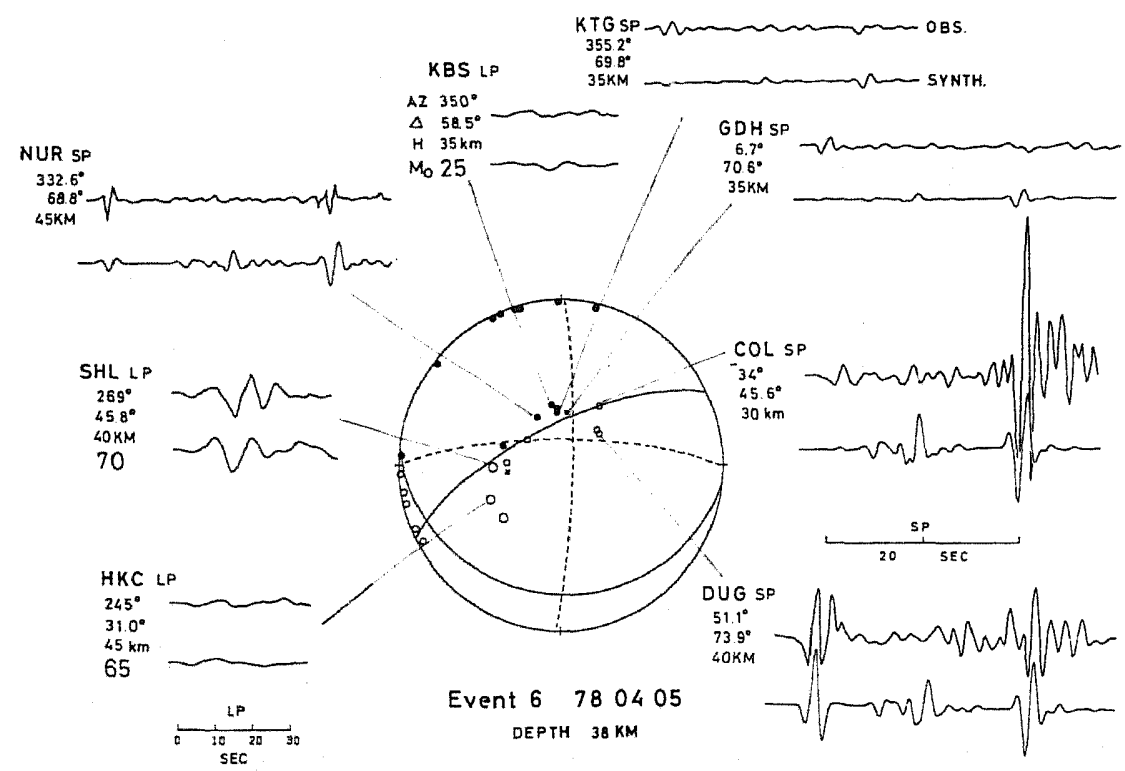

Fig. 15. A mechanism diagram and a comparison of the synthetics with the observed P-wave records for Event 6. Another possible strike-slip solution is indicated by the broken line. The small solid and open circles at the circumference are the data from local stations in Hokkaido and Honshu. The synthetics shown are calculated based on the mechanism solution indicated by the solid line.

the nodal planes for this event (Fig. 17). We therefore adopted YosHir's (1979c) solution (Fig. 18) for this case. Though the nodal planes of his solution are still not constrained well, it is clear that the solution is dominantly a reverse fault type. Only SP and one LP records are available for this event. Figure 19 shows a comparison of the synthetics calculated for various source depths at CMC with the observed record. The largest later phase is predicted to be pwP and using this we can determine the source depth of about $48 \mathrm{~km}$.

Though the fit of the synthetics with the observed records is marginal in Fig. 17, one available LP record at QUE shows that the depth obtained from the SP records can also fit the LP record and the event is undoubtedly deeper than the other events. This LP record is, however, not used for the depth determination because it does not constrain the depth well. Similarly, we should not place much confidence on the source time function for LP, seismic moment, and stress drop for this event in Table 4 because only one LP record is available and the $\mathrm{S} / \mathrm{N}$ ratio of the record is not good. 


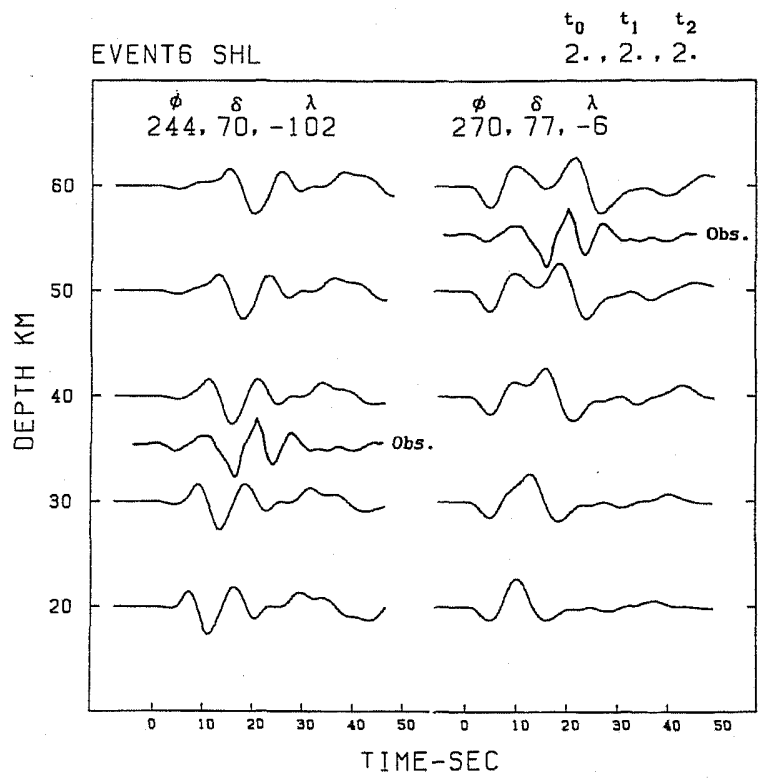

Fig. 16. A comparison of the synthetics for the two possible solutions in Fig. 13 at SHL. The left is calculated based on the solution indicated by the solid line in Fig. 15, and the right based on the solution indicated by the broken line in Fig. 15. The observed record is best fitted by the synthetics at the left at $40 \mathrm{~km}$ depth.

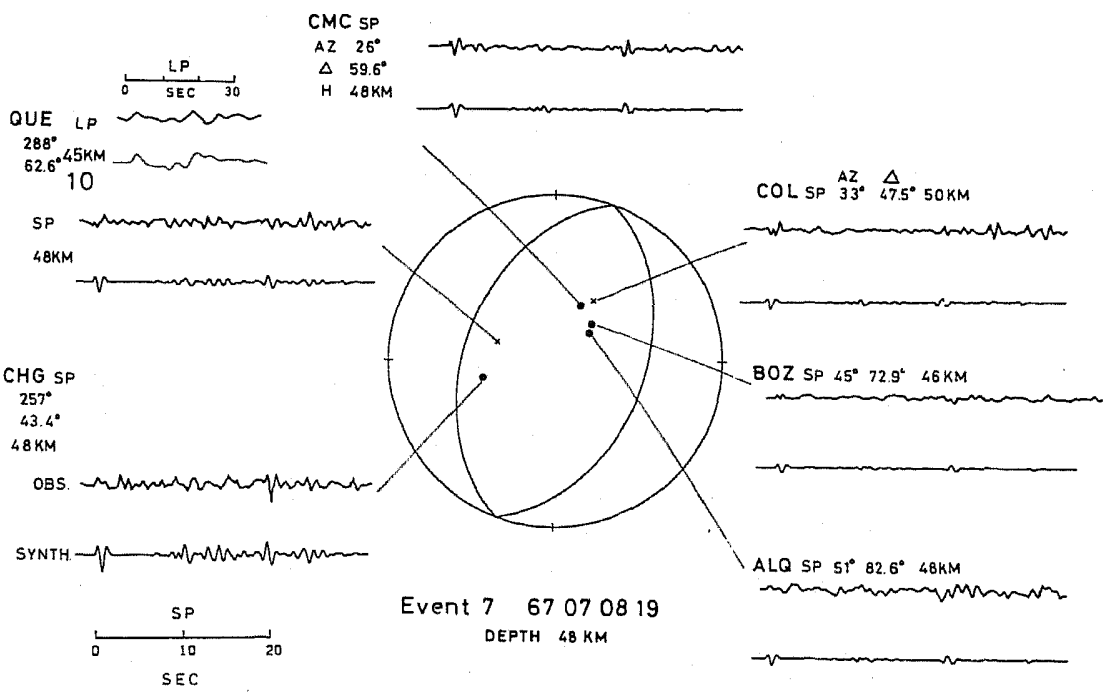

Fig. 17. A mechanism diagram and a comparison of the synthetics with the observed P-wave records for Event 7. 


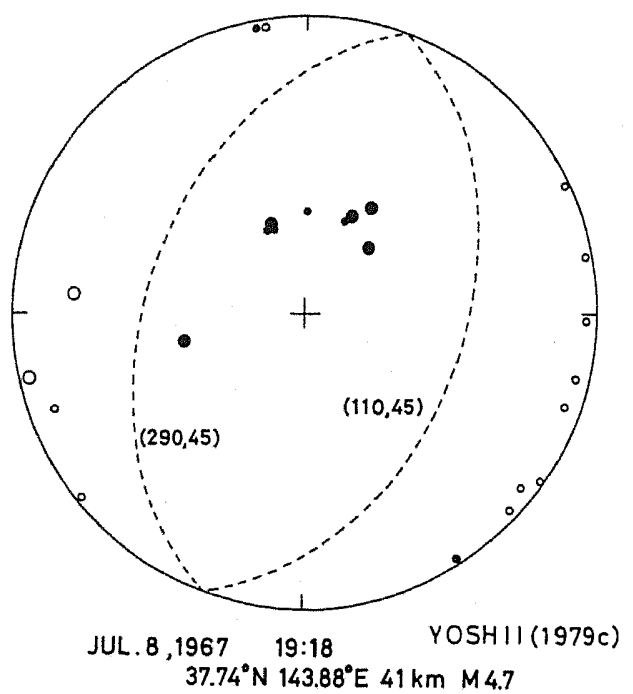

Fig. 18. The mechanism diagram for Event 7 by YoshiI (1979c). Large and small circles are the first motions from LP and SP records, respectively.

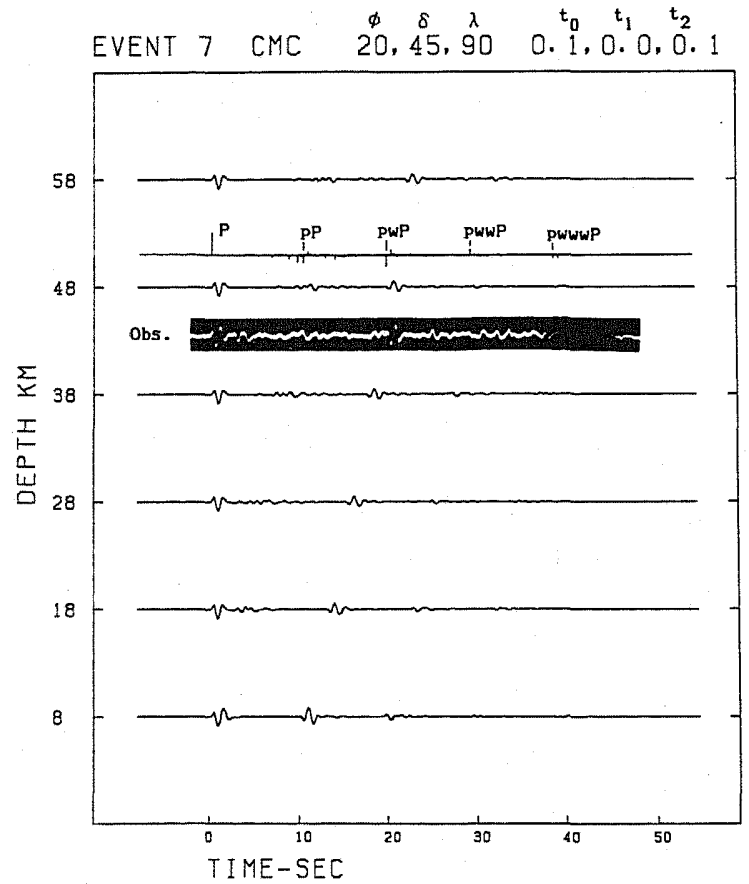

Fig. 19. A comparison of the synthetics for various depths at CMC for Event 7 . The pulses calculated for $48 \mathrm{~km}$ depth are also shown above the synthetics at this depth. The observed record is best fitted by the synthetics at this depth. 


\section{Discussion}

\subsection{Structure of the outer trench wall}

The major fault pattern in the outer slope of the Japan trench consists of fault sieps and horst-graben structures striking parallel or sub-parallel to the trench (LudWig et al., 1966; TAMAKI et al., 1977; IWABUCHI, 1980; SHIPBoard SCIENTIFIC PARTY, 1980; KoBayashi et al., 1987; CADET et al., 1987). This faulting pattern has been ascribed to bending of the plate prior to subduction (e.g., LuDwiG et al., 1966). The normal faulting caused by Events 1-5 includes both senses of motion: the arcside and sea-side are both downthrown. We thus believe that the faulting is generated by the same stresses that caused the horst-graben structures. In this respect, it is important to note that Events 1-3, having both senses of motion, occurred within two days during a swarm (YosHII, 1981). YosHII (1981, 1979 a, c) studied fault plane solutions for Events 1 and 3 and also fault types for other smaller events using the polarity of P-waves at the two nearest WWSSN stations in Japan (MAT and SHK) and the radiation pattern of Rayleigh waves. He found that fault types of most events could be classified as similar to either Event 1 or Event 3 . He ascribed this swarm activity to the formation of the horst-graben structure in the outer trench wall. However, his solution for Event 3, thrusting with a very low dip angle, posed some difficulty in the interpretation of this event in terms of bending (YosHII, 1979 c). Our revised vertical fault solution (Fig. 9) is more consistent with the formation of the horst-graben structure.

Recently, another trend of the normal faults, striking ENE, has been found using a Seabeam survey during the French-Japanese KAIKO project (CADET $e t$ al., 1987; LALlemand et al., 1986). This trend is parallel to the magnetic anomaly lineations off the Japan trench (HILDE et al., 1976). CADET et al. (1987) and LALLEMAND et al. (1986) interpreted these normal faults as reactivation of the old structure formed during accretion at the mid-ocean ridges. It is noted that the nearly vertical nodal plane of Event 6 is striking ENE. This event might represent reactivation of the structure parallel to the magnetic fabrics.

\subsection{Comparison with OBS observations}

OBS observations (NAGUmo et al., 1984; KaSAHARA et al., 1982) show clusters of activity near the trench axis (shaded in Fig. 2) where the great 1933 Sanriku earthquake occurred. The activity is divided into two parts: the landward activity beneath the trench axis which extends to $45 \mathrm{~km}$ depth with a nearly vertical trend, and the shallow $(<8 \mathrm{~km})$ linear activity further seaward. Hirata et al. (1983) also reported scattered seismicity, detected by the OBS survey, along the outer trench slope north of the great 1933 event (Fig. 2, small solid circles). The depth of this activity is less than $50 \mathrm{~km}$ beneath the trench axis and less than $30 \mathrm{~km}$ further seaward. The depth distribution of the trench events down to $48 \mathrm{~km}$ in this study is consistent with these OBS observations for smaller events.

The NS trending normal faulting observed in the seismic profiles occurs about 
$80 \mathrm{~km}$ seaward from the trench axis (LuDWIG et al., 1966; TAMAKI et al., 1977; CADET et al., 1987). The area almost coincides with the area where the microseismicity is observed by OBS. The epicenters of the events in this study, however, distribute within $30 \mathrm{~km}$ seaward from the trench axis. This is probably not an artifact due to mislocations of the teleseismic events since the errors of ISC locations are on the order of 20-30 km (UTSU, 1975; BARAZANGI and ISACKS, 1979; ICHIKAWA, 1979). This may thus indicate that larger events occur more frequently in the slope near the trench axis than in the slope further seaward.

\subsection{The 1933 Sanriku earthquake}

The epicenters of Events 1-3 and 6 are located within the aftershock area of the 1933 Sanriku $\left(M_{\mathrm{w}}=8.4\right)$ earthquake (Fig. 2). There has been some debate on the rupture extent of the 1933 normal fault earthquake. KANAMORI (1971) stated that it extended almost through the entire thickness of the lithosphere to $70 \mathrm{~km}$ depth, based on the aftershock distribution reported by the Japan Meteorological Agency. Recent papers (HANKS, 1979; CHAPPLE and ForsyTH, 1979) have questioned this estimate.

The 1977 Indonesian earthquake is a normal fault earthquake of a similar size $\left(M_{s}=8.1\right)$ at the Java trench. There has also been debate on the rupture extent for this event. Given and KANAMORI (1980) and ZhANG and KanAmORI (1985) claimed that the rupture extended over $80 \mathrm{~km}$. In contrast, SILVER and JORDAN (1983) obtained a centroid depth shallower than $20 \mathrm{~km}$ from the moment spectra. Consistent with this centroid depth, FITCH et al. (1981) found that the depth range of major aftershocks is $8-24 \mathrm{~km}$ and KIKUCHI and FUKAO (1987), and LYNNES and LAY (1988) obtained the source extent not deeper than $35 \mathrm{~km}$ from the analysis of long-period body waves.

The stress state within the lithosphere known from smaller size earthquakes at the Japan trench would help to resolve the above ambiguity. The normal fault extended over $70 \mathrm{~km}$ depth would imply that the lithosphere is entirely under tension. However, the compressional event (Event 7) at $41 \mathrm{~km}$ depth below the seafloor and located only $80 \mathrm{~km}$ south of the aftershock area of the 1933 event.(Fig. 2) and the normal fault event within the aftershock area (Event 6), with stress axes unrelated to bending, at $31 \mathrm{~km}$ depth below the seafloor indicate that the whole lithosphere is probably not under deviatoric tension.

This conjecture is also supported by the existence of the double seismic zone with both down-dip compressional and tensional stresses beneath northern Honshu (HaSegawa et al., 1978; Yoshil, $1979 \mathrm{a}$; KawaKatsu and Seno, 1983) which indicates that the slab at the $50-200 \mathrm{~km}$ depth range is not under deviatoric tension. We therefore infer that the 1933 Sanriku event is likely to be a large bending earthquake which would have ruptured the upper part of the lithosphere.

The above inference might not hold if the stress state of the slab changes significantly associated with the cycles of nearby large interplate earthquakes as claimed by Christensen and Ruff (1987) and Astiz and Kanamori (1986). 
However, we feel this is not the case for the Sanriku area because the thrust zone seaward of the Sanriku great earthquake is largely decoupled (KAwAKATSU anc SENO, 1983). Northwest of the Sanriku earthquake is the thrust zone where large interplate earthquakes occurred in $1896\left(M_{s}=8.6\right)$ and in $1968\left(M_{\mathrm{s}}=8.1\right)$ (see KAWAKATSU and SENO, 1983), and this zone might disturb the stress state of the slab in the Sanriku fault area. Note, however, that the 1933 Sanriku event occurred in between and not after these two large earthquakes as predicted by Christensen and Ruff's strongly coupled case. Furthermore, the period of the present study includes the post-seismic period of the 1968 event, and we do not see any indication for the entire lithospheric tension for this period as was shown above. To confirm the above inference on the Sanriku earthquake, however, we have to monitor the stress state of the slab for a longer time period in the future.

\subsection{Bending models}

To date, plate bending at the Japan trench has been modeled only by Jones et al. (1978) using the flexure of a thin elastic plate. They obtained an effective elastic thickness of $78 \mathrm{~km}$ for one profile. They also obtained an elastic thickness of 67 and $72 \mathrm{~km}$ for two other profiles, though these profiles are not well fitted by the elastic model. These values of elastic thickness are larger than those estimated in the western Pacific region (MCAdoo and MARTin, 1984; Jones et al., 1978). For example, MCADOO and MARTIN (1984) obtained 42, 63, and $51 \mathrm{~km}$ for Kurile, Bonin, and Mariana, respectively. The $41 \mathrm{~km}$ depth for the compressional event and the $2-16 \mathrm{~km}$ depths for the tensional events below the seafloor in this study show the depth of the neutral surface between 20 and $40 \mathrm{~km}$. The deeper normal fault event at $31 \mathrm{~km}$ depth whose fault strike is perpendicular to the trench also indicates that the bending stress at this depth is not large and the neutral surface would be close to this depth. Also note that the source time of this event is significantly larger, thus resulting in the estimated stress drop smaller than the other events. If we abandon the constant rupture velocity assumption used for the stress drop calculation, this may instead mean a rupture occurred more slowly for this event with a static stress drop similar to the other events. In any case, interestingly, the rupture characteristics of this event located around the neutral surface is different from the other bending events. Though the above estimates for the neutral surface depth from the earthquakes are not necessarily inconsistent with the above $78 \mathrm{~km}$ thick elastic plate by JONES et al. (1978), the elastic thickness of $40-60 \mathrm{~km}$ interpolated from the two adjacent trenches (Kurile and Bonin) seems more consistent with the stress distribution within the lithosphere derived from the earthquakes. Because there is a large uncertainty for the estimate of the elastic thickness if we use topographic profiles (MCADOO and MARTIN, 1984), we need more accurate estimates for the elastic thickness at this trench using the Seasat geoid data. Furthermore, there still remains a question whether elastic plate modeling is appropriate for modeling the bending of oceanic lithosphere. More seismicity and accurate focal depth and mechanism data may place further constraints on the bending models. 


\section{Conclusions}

We have determined accurate fault plane solutions and focal depths for seven events along the Japan trench outer slope, using the comparison between synthetic and observed seismograms of long- and short-period teleseismic records. We have found that short-period records are particularly useful for small-size events. The five shallow normal fault earthquakes and one deep reverse fault are in accord with the plate bending interpretation for these events. The occurrence of two types of faulting for the normal fault solutions, showing both continental and oceanic side downthrown, is likely to be associated with the formation of the horst-graben structure in the outer trench slope near the trench axis.

The one normal fault event with intermediate depth ( $31 \mathrm{~km}$ below the seafloor) cannot be interpreted in terms of the bending stress; its nodal plane is parallel to the ENE magnetic fabrics in the region and would represent reactivation of the structure produced during seafloor spreading. It could also be an indication that the neutral surface depth of the bending lithosphere is around this depth, as it implies that the bending stress is not large at this depth.

The occurrence of both normal and reverse fault solutions at the Japan trench suggests that the lithosphere is not under deviatoric tension for the past tens of years, consistent with the observation of the double seismic zone in the deeper portion of the slab. The 1933 great Sanriku normal fault earthquake is likely to have been a large bending event, unless the stress state within the slab does not change significantly with time. The neutral surface depth estimated from the earthquakes suggests the plate thickness of about $60 \mathrm{~km}$, in the Japan trench area which is consistent with the observed elastic thickness in the adjacent regions in the western Pacific subduction zones.

We are grateful to Seth Stein and Doug Wiens for their critical review of the manuscript, and Toshikatsu Yoshii for providing his unpublished data and discussions.

\section{REFERENCES}

ASTIZ, L. and H. KANAMORI, Interplate coupling and temporal variation of mechanisms of intermediate-depth earthquakes in Chile, Bull. Seismol. Soc. Am., 76, 1614-1622, 1986.

BARAZANGI, M. and B. L. ISACKS, A comparison of the spatial distribution of mantle earthquakes determined from data produced by local and by teleseismic networks for the Japan and Aleutian arc, Bull. Seismol. Soc. Am., 69, 1763-1770, 1979.

Bodine, J. H., M. S. STECKLER, and A. B. WATtS, Observation of flexure and the rheology of the oceanic lithosphere, J. Geophys. Res., 86, 3695-3707, 1981.

Cadet, J. P., K. Kobayashi, J. Aubouin, J. Boulegue, C. Deplus, J. Dubois, R. Von Heune, L. Jolivet, T. Kanazawa, J. Kasahara, K. Koizumi, S. Lallemand, Y. Nakamura, G. Pautot, K. Suyehiro, S. Tani, H. Tokuyama, and T. Yamazaki, The Japan trench and its juncture with the Kuril trench: Cruise results of the Kaiko project, Leg 3, Earth Planet. Sci. Lett., 83, 267-284, 1987. 
CARPENTER, E. W., Absorption of elastic waves-An operator for constant Q mechanism, Rep. 0-43166, At. Weapons Res. Estab., London, 1966.

Chapple, W. M. and D. W. Forsyth, Earthquakes and bending of plates at trenches, $J$. Geophys. Res., 84, 6729-6749, 1979.

Chase, T. E. and H. W. Menard, Bathymetric Atlas of the Northwestern Pacific Ocean, U. S. Naval Oceanographic Office, Washington, D.C., 50 pp., 1969.

Chen, T. and D. W. ForsyTH, A detailed study of two earthquakes seaward of the Tonga trench: Implications for mechanical behavior of the oceanic lithosphere, J. Geophys. Res., 83, 4995-5003, 1978.

ChINN, D. A. and B. L. IsACKs, Accurate source depths and focal mechanisms of shallow earthquakes in western south America and in the New Hebrides island arc, Tectonics, 2, 529-563, 1983.

Christensen, D. H. and L. J. Ruff, Seismic coupling and outer-rise earthquakes, J. Geophys. Res., 1987 (in press).

Fitch, T. J., R. G. North, and M. W. Shields, Focal depths and moment tensor representations of shallow earthquakes associated with the great Sumba earthquake, $J$. Geophys. Res., 86, 9357-9374, 1981.

ForsYTH, D. W., Comparison of mechanical models of the oceanic lithosphere, J. Geophys. Res., 85, 6364-6368, 1980.

FORSYTH, D. W., Determination of focal depths of earthquakes associated with the bending of oceanic plate at trenches, Phys. Earth Planet. Inter., 28, 141-160, 1982.

FukaO, Y. and M. KIKUCHI, Source retrieval for mantle earthquakes by iterative deconvolution of long-period P-waves, Tectonophysics, 144, 249-269, 1987.

Given, J. W. and H. Kanamori, The depth extent of the 1977 Sumbawa, Indonesia, earthquake (abstract), EOS Trans. AGU, 61, 1044, 1980.

HANKS, T. C., Deviatoric stresses and earthquake occurrence at the outer rise, J. Geophys. Res., 84, 2343-2347, 1979.

Hasegawa, A., N. Umino, and A. TAKagi, Double-planed structure of the deep seismic zone in the northeastern Japan arc, Tectonophysics, 47, 43-58, 1978.

HeRmanN, R. B., Focal depth determination from the signal character of long-period Pwaves, Bull. Seismol. Soc. Am., 66, 1221-1232, 1976.

HerRIN, E., Introduction to "1968 seismological tables for p phases," Bull. Seismol. Soc. Am., 58, 1193-1225, 1968.

HILDE, T. W. C., N. IseZAKI, and J. M. WAGEMAN, Mesozoic sea-floor spreading in the north Pacific, Geophys. Monogr., AGU, 19, 203-226, 1976.

Hirata, N., T. Yamada, H. Shimamura, H. Inatani, and K. Suyehiro, Spatial distribution of microearthquakes beneath the Japan Trench from ocean bottom seismographic observations, Geophys. J. R. Astron. Soc., 73, 653-670, 1983.

ICHIKAWA, M., Determination of hypocenters of earthquakes occurring off the east coast of northern Honshu, Q. J. Seismol., 43, 59-65, 1979.

IWABuCHI, Y., Topography of trenches in the adjacent seas of Japan, Mar. Geod., 4, 121-140, 1980.

JAEGER, J. C. and N. G. W. COOK, Fundamentals of Rock Mechanics, 3rd Edition, Chapman \& Hall, London, 593 pp., 1979.

Jones, G. M., W. C. Hilde, G. F. Sharman, and D. C. Agnew, Fault patterns in outer trench walls, J. Phys. Earth, 26, Suppl., S85-S101, 1978. 
Kanamori, H., Seismological evidence for a lithospheric normal faulting, the Sanriku earthquake of 1933, Phys. Earth. Planet. Inter, 4, 289-300, 1971.

Kasahara, J., S. Nagumo, S. Koresawa, Y. Nishi, and H. Sugimoto, A linear trend of hypocenter distribution in the outer slope region of the Japan trench revealed by OBS array-Preliminary report, Bull. Earthq. Res. Inst., Univ. Tokyo, 57, 83-104, 1982.

KawaKatsu, H. and T. Seno, Triple seismic zone and the regional variation of seismicity along the northern Honshu arc, J. Geophys. Res., 88, 4215-4230, 1983.

$\mathrm{KIKUCH}, \mathrm{M}$. and Y. FUKAO, Inversion of long-period $\mathrm{P}$ waves from great earthquakes along subduction zones, Tectonophysics, 144, 231-247, 1987.

Kobayashi, K., J. P. Cadet, J. Aubouin, J. Boulegue, C. Deplus, J. Dubois, R. Von Heune, L. Jolivet, T. Kanazawa, J. Kasahara, K. Koizumi, S. Lallemand, Y. Nakamura, G. Pautot, K. Suyehiro, S. Tani, H. Tokuyama, and T. Yamazaki, Normal faulting of the Daiichi-Kashima Seamount in the Japan trench revealed by the Kaiko cruise, Leg 3, Earth Planet. Sci. Lett., 83, 257-266, 1987.

Kroeger, G. C. and R. J. Geller, An efficient method for synthesizing teleseismic body waves for shallow sources in a vertically stratified medium, J. Geophys. Res., 1986 (in press).

Lallemand, S., J. P. CADET, and L. Jolivet, Tectogenesis process at the base of the Japan trench landward wall off Sanriku (NE Japan): Rejuvenation of oceanic faults below the margin, C. R. Acad. Sci. Paris, 303, Ser. II, 319-324, 1986.

Ludwig, W. J., J. I. Ewing, S. Murauchi, N. Den, S. Asano, H. Hotta, M. Hayakawa, T. Asanuma, K. ICHIKaWA, and I. NoGuchi, Sediments and structure of the Japan trench, J. Geophys. Res., 71, 2121-2137, 1966.

LYNNES, C. S. and T. LAY, Source process of the great 1977 Sumba earthquake, J. Geophys. Res., 1988 (in press).

MCADoo, D. C. and C. F. MARTIN, Seasat observations of lithospheric flexure seaward of trenches, J. Geophys. Res., 89, 3201-3210, 1984.

Murauchi, S., T. Asanuma, H. Taguchi, H. Kinoshita, I. Yokoyama, and H. NaKatani, Seismic prospecting near the trench off Sanriku by sono-buoy method, Abstr. Seismol. Soc. Jpn., 2, 128, 1977 (in Japanese).

Nagumo, S., J. Kasahara, and S. Koresawa, Hypocenter distribution in the Japan trench region, off Sanriku, northeast Japan, determined by an ocean-bottom seismometer array observation, Bull. Earthq. Res. Inst., Univ. Tokyo, 59, 441-465, 1984.

SENO, T. and G. C. KROEGER, A reexamination of earthquakes previously thought to have occurred within the slab between the trench axis and double seismic zone, northern Honshu arc, J. Phys. Earth, 31, 195-216, 1983.

Seno, T. and B. Pongsawat, A triple-planed structure of seismicity and earthquake mechanisms off Miyagi Prefecture, northeastern Honshu, Japan, Earth Planet. Sci. Lett., 55, 25-36, 1981.

ShIPboard Scientific ParTy, Initial Report Deep Sea Drilling Project, Washington, D.C., U. S. Governmental Printing Office, 56-57, 1980.

SILVER, P. G. and T. H. JORDAN, Total-moment spectra of fourteen large earthquakes, $J$. Geophys. Res., 88, 3273-3293, 1983.

Stein, S. and D. A. WiEns, Depth determination for shallow teleseismic earthquakes: Method and results, Rev. Geophys., 24, 806-832, 1986.

Stein, S., J. F. Engeln, D. A. Wiens, K. Fujita, and R. C. Speed, Subduction seismicity and 
tectonics in the lesser Antilles arc, J. Geophys. Res., 87, 8642-8664, 1982.

Tamaki, K., Y. Inouchi, F. Murakami, and E. Honza, Continuous seismic reflection profiling survey, Cruise Rep., Geol. Surv. Jpn., 7, 50-71, 1977.

UTsu, T., Seismology, Kyoritsu Publishing Company, Tokyo, 286 pp., 1975 (in Japanese).

WARD, S. N., Ringing P waves and submarine faulting, J. Geophys. Res., 84, 3057-3062, 1979.

WARD, S. N., Body wave inversion: Moment tensors and depths of oceanic intraplate bending earthquakes, J. Geophys. Res., 88, 9315-9330, 1983.

WatTs, A. B. and M. TAlWANI, Gravity anomalies seaward of deep-sea trenches and their tectonic implications, Geophys. J. R. Astron. Soc., 36, 57-90, 1974.

WiEns, D. A., Effects of near source bathymetry on teleseismic P waveforms, Geophys. Res. Lett., 14, 761-764, 1987.

YoshiI, T., Proposal of the "aseismic front," Zisin 2, 28, 365-367, 1975 (in Japanese).

YosHiI, T., A detailed cross-section of the deep seismic zone beneath Japan, Tectonophysics, 55, 349-360, 1979 a.

Yoshil, T., Compilation of geophysical data around the Japanese islands, Bull. Earthq. Res. Inst., Univ. Tokyo, 54, 75-117, 1979 b (in Japanese).

YoshiI, T., Reverse fault type near the trench axis, Abstr. Seismol. Soc. Jpn., 2, 76, 1979c (in Japanese).

Yoshil, T., Earthquake swarm in August 1969 near the Japan trench, Abstr. Seismol. Soc. $J p n ., 2,57,1981$ (in Japanese).

ZhANG, J. and H. KANAMORI, Determination of the vertical extent of faulting of large earthquakes using long-period surface waves, EOS, Trans. AGU, 66, 963, 1985. 